\title{
Yield and Seed Oil Content Response of Dwarf, Rapid-cycling Brassica to Nitrogen Treatments, Planting Density, and Carbon Dioxide Enrichment
}

\author{
Jay Frick ${ }^{1}$, S. Suzanne Nielsen ${ }^{2}$, and Cary A. Mitchell ${ }^{3}$ \\ NationalAeronautics and Space Administration Specialized CenterofResearchandTraining in Bioregenerative \\ Life Support, Purdue University, 1165 Horticulture Building, West Lafayette, IN 47907-1165
}

\begin{abstract}
Additional index words. Brassica napus, bioregenerative life support, CELSS, controlled-environment agriculture, hydroponics, NASA

Abstract. Effects of $\mathrm{N}$ level (15 to $30 \mathrm{~mm}$ ), time of $\mathrm{N}$ increase (14 to 28 days after planting), and planting density (1163 to 2093 plants $/ \mathrm{m}^{2}$ ) were determined for crop yield responses of dwarf, rapid-cycling brassica (Brassica napus L., CrGC 52, Genome: ACaacc). Crops were grown in solid-matrix hydroponic systems and under controlled-environment conditions, including nonsupplemented (ambient) or elevated $\mathrm{CO}_{2}$ concentrations $\left(998 \pm 12 \mu \mathrm{mol}^{\circ} \mathrm{mol}^{-1}\right)$. The highest seed yield rate obtained $\left(4.4 \mathrm{~g} \cdot \mathrm{m}^{-2} \cdot \mathrm{day}^{-1}\right)$ occurred with the lowest $\mathrm{N}$ level $(15 \mathrm{~mm})$ applied at the latest treatment time (day 28$)$. In all trials, $\mathrm{CO}_{2}$ enrichment reduced seed yield rate and harvest index by delaying the onset of flowering and senescence and stimulating vegetative shoot growth. The highest shoot biomass accumulation rate $\left(55.5 \mathrm{~g} \cdot \mathrm{m}^{-2} \cdot \mathrm{day}^{-1}\right)$ occurred with the highest $\mathrm{N}$ level $(30 \mathrm{~mm})$ applied at the earliest time (day 14). Seed oil content was not significantly affected by $\mathrm{CO}_{2}$ enrichment. Maximum seed oil content (30\% to 34\%, dry weight basis) was obtained using the lowest $\mathrm{N}$ level (15 mM) initiated at the latest treatment time (day 28). In general, an increase in seed oil content was accompanied by a decrease in seed protein. Seed carbohydrate, moisture, and ash contents did not vary significantly in response to experimental treatments. Effects of $\mathrm{N}$ level and time of $\mathrm{N}$ increase were consistently significant for most crop responses. Planting density was significant only under elevated $\mathrm{CO}_{2}$ conditions.
\end{abstract}

The U.S. National Aeronautics and Space Administration (NASA) is engaged in an effort to perfect its concept of a controlled ecological life-support systems (CELSS). These systems, which will exist as finely tuned combinations of physico-chemical, mechanical, and biological components, will play an essential role in the future of human space habitation. A CELSS will be designed to recycle $\mathrm{O}_{2}$, provide potable water, and produce fresh food during long-term space missions during which resupply is either impractical or impossible (Hoff et al., 1983).

The vegetarian diet proposed for a CELSS will derive most of its calories from complex carbohydrates. However, vegetable oil also will be necessary to provide essential fatty acids, cooking oil, caloric supplementation, and satiety in the diet. NASA currently recommends that at least $20 \%$ of the total dietary energy in a CELSS be derived from high-quality oil that lacks cholesterol (Wade, 1989).

Brassica napus is being considered as an oilseed crop for use in a CELSS. This species has food-quality and cultural characteristics that make it a promising CELSS candidate. The dwarf variety tested in this study cycles quickly under controlled-environment conditions, going from seed to seed in 55 days or less. In addition, the seeds contain a high-quality oil that is low in saturated fats.

Important evaluation criteria for CELSS candidate species include increasing edible harvest while minimizing resource in-

Received for publication 3 Jan. 1994. Accepted for publication 14 June 1994 Journal paper no. 14055 of the Purdue Univ. Agricultural Experiment Station. Research supported in part by NASA grant NAGW-2329. We gratefully acknowledge MaryAnn Rounds and Deb Smart, Dept. of Food Science, Purdue Univ., for performing the seed composition analysis and Paul Williams, Dept. of Plant Pathology, Univ. of Wisconsin, for providing the rapid-cycling brassica germplasm. The cost of publishing this paper was defrayed in part by the payment of page charges. Under postal regulations, this paper therefore must be hereby marked advertisement solely to indicate this fact.

${ }^{1}$ Graduate research assistant, Dept. of Horticulture.

${ }^{2}$ Professor, Dept. of Food Science.

${ }^{3}$ Professor, Dept. of Horticulture; to whom reprint requests should be addressed. puts and growing volume requirements. To realize the genetic yield potential of Brassica napus, crop growth and yield must be evaluated under optimizing environmental conditions with minimum stress. Determining optimum conditions can be a complex task since environmental variables interact with plant growth in a variety of ways (Milthorpe and Moorby, 1979).

The objective of this study was to test the effects of varying $\mathrm{N}$ level, time of $\mathrm{N}$ increase, and planting density on crop yield responses of dwarf, rapid-cycling Brassica napus. Specifically, we examined seed yield rate, seed oil content, shoot biomass production rate, and shoot caloric harvest index (CHI) as our primary crop responses. The experiments were conducted under nonsupplemented (ambient) and elevated $\mathrm{CO}_{2}$ conditions. Statistical models were then developed for each crop response, and relative significance and potential interactions among the experimental variables were determined.

\section{Materials and Methods}

Experimental procedure. Brassica napus seeds (Wisconsin Fast Plants, Madison, Wis.) were germinated in quarter-strength Hoagland's no. 1 nutrient solution (Hoagland and Arnon, 1950), $\mathrm{pH}$ 5.6, in petri dishes sealed with Parafilm. After $24 \mathrm{~h}$, seeds were selected for radicle emergence and planted in solid matrix, capillary-wicking hydroponic systems (Leisure Garden 1250; Pathway Systems, Winston-Salem, N.C.).

The growth medium, which had been rinsed with deionized water before planting, was a mixture of 2 vermiculite : 1 perlite $(\mathrm{v} / \mathrm{v})$. Planting density was one of three levels: 1163, 1628, or 2093 plants/ $\mathrm{m}^{2}$. Immediately after planting, each system was covered with a single layer of plastic wrap, and reservoirs were filled with $800 \mathrm{ml}$ of single-strength ( $1 \mathrm{x})$ Hoagland's nutrient solution ( $\mathrm{pH} 5.55 \pm 0.05$ ) containing 2 rather than $15 \mathrm{~mm} \mathrm{~N}$ as in the standard $1 \mathrm{x}$ formula.

Hydroponic systems were randomly placed on a table in a walkin growth chamber (MK-11-77; Environmental Growth Cham- 
bers, Chagrin Falls, Ohio). Conditions were maintained at a relative humidity of $75 \% \pm 5 \%$, and a diurnal temperature cycle of 25 and $20 \mathrm{C}$ for 20 and $4 \mathrm{~h}$, respectively. Photosynthetic photon flux (PPF) was provided by $215-\mathrm{W}$ VHO fluorescent lamps, and photoperiod was constant $(24 \mathrm{~h})$. PPF levels varied slightly between experiments. For the ambient- $\mathrm{CO}_{2}$ experiment, PPF averaged $505 \mu \mathrm{mol} \cdot \mathrm{m}^{-2} \cdot \mathrm{s}^{-1}$ (LI-1776 solar monitor; LI-COR, Lincoln, Neb.). PPF averaged $488 \mu \mathrm{mol} \cdot \mathrm{m}^{-2} \cdot \mathrm{s}^{-1}$ during the elevated-CO experiment. These PPF averages reflect a $3.4 \%$ difference between the two experiments.

After $24 \mathrm{~h}$, the plastic wrap was removed. To ensure proper plant densities, replacement transplants were positioned where seedlings did not emerge. Less than $5 \%$ of total seedlings in a given system was transplants.

For the first 13 days of growth, solution reservoirs were refilled as needed with nutrient solution containing $2 \mathrm{~mm}$ N. Nitrogen was shifted to higher levels in some trays beginning on day 14 (Table 1). Nitrogen level was increased by replacing the initial nutrient solution with a solution containing either $15,22.5$, or $30 \mathrm{~mm} \mathrm{~N}$ (Table 2). Similar treatments were initiated on days 21 or 28 . These three treatment times corresponded to preflowering, flowering, and postflowering developmental stages, respectively. In all trays, once $\mathrm{N}$ was increased, fresh solution at the elevated $\mathrm{N}$ treatment level was provided as needed for the rest of the crop-production cycle.

For $\mathrm{CO}_{2}$ enrichment studies, a mass-flow valve (Side-Trak; Sierra Instruments, Carmel Valley, Calif.) released $\mathrm{CO}_{2}$ into the chamber as needed. The valve was controlled by a mass-flow control system (Sierra FloBox, Series 900; Sierra Instruments), and additional $\mathrm{CO}_{2}$ was provided from a tank of compressed gas. Chamber air was sampled with an infrared gas analyzer (PIR-

Table 1. Experimental variables and their treatment levels.

\begin{tabular}{lccc}
\hline \hline Variable & Units & Symbol & Levels \\
\hline Nitrogen $\left(\mathrm{NO}_{3}^{-}\right)$ & $\mathrm{mM}$ & $\mathrm{N}$ & $15,22.5$, or 30 \\
Time of $\mathrm{N}$ increase & $\mathrm{DAP}^{\mathrm{z}}$ & $\mathrm{t}$ & 14,21, or 28 \\
Planting density & plants $/ \mathrm{m}^{2}$ & $\mathrm{p}$ & 1163,1628, or 2093 \\
\hline
\end{tabular}

zDays after planting.

Table 2. Elemental composition of modified nutrient solutions.

\begin{tabular}{lcccc}
\hline \hline & \multicolumn{4}{c}{ N treatment level } \\
\cline { 2 - 5 } Element & $0.13 \mathrm{x}$ & $1 \mathrm{x}$ & $1.5 \mathrm{x}$ & $2 \mathrm{x}$ \\
\hline $\mathrm{N}$ & 2 & $(m M)$ & 22.5 & 30 \\
$\mathrm{P}$ & 1 & 15 & 1 & 1 \\
$\mathrm{~K}$ & 6 & 1 & 8.5 & 11 \\
$\mathrm{~S}$ & 2 & 6 & 2 & 2 \\
$\mathrm{Ca}$ & 5 & 5 & 7.5 & 10 \\
$\mathrm{Mg}$ & 2 & 2 & 2 & 2 \\
$\mathrm{Cl}$ & 13 & --- & --- & --- \\
& & $(\mu M)$ & & \\
$\mathrm{B}$ & 46 & 46 & 46 & 46 \\
$\mathrm{Fe}$ & 44 & 44 & 44 & 44 \\
$\mathrm{Cl}$ & -- & 18 & 18 & 18 \\
$\mathrm{Mn}$ & 9.2 & 9.2 & 9.2 & 9.2 \\
$\mathrm{Zn}$ & 0.77 & 0.77 & 0.77 & 0.77 \\
$\mathrm{Cu}$ & 0.32 & 0.32 & 0.32 & 0.32 \\
$\mathrm{Mo}$ & 0.11 & 0.11 & 0.11 & 0.11 \\
\hline
\end{tabular}

$\overline{\text { Large } \mathrm{Cl} \text { differences due to } \mathrm{KCl} \text { and } \mathrm{CaCl}_{2} \text { salts used to maintain } \mathrm{K} \text { and }}$ $\mathrm{Ca}$ at nonlimiting levels in $0.13 \mathrm{x} \mathrm{N}(2 \mathrm{~mm} \mathrm{~N})$ nutrient solution.
2000; Horiba Instruments, Irvine, Calif.), which provided a feedback data signal to the flow controller. Chamber $\mathrm{CO}_{2}$ was set at $1000 \mu \mathrm{mol} \cdot \mathrm{mol}^{-1}$ and was maintained at this level ${ }^{2}(998 \pm 12$ $\mu \mathrm{mol} \cdot \mathrm{mol}^{-1}$ ) during the experiment.

After the 55-day cropping cycle, nutrient solution was withheld and plants were allowed to air dry for 7 additional days. After harvest, all shoot biomass except seeds was dried for $72 \mathrm{~h}$ in a forced-air oven at $75 \mathrm{C}$ and shoot tissue weights were determined. Because of the 7-day dry-down procedure, it was not possible to separate and measure root biomass accurately. The dry, fibrous roots disintegrated readily during attempts to separate them from the solid matrix.

An operating CELSS will be an extremely dynamic and complex system, with control algorithms dependent on raw-material production rates and resource consumption rates. For this reason, we have reported canopy seed yield and shoot biomass production data in terms of their associated yield rates (i.e., $\mathrm{g} \cdot \mathrm{m}^{-2} \cdot \mathrm{day}^{-1}$ ), with production rates determined with respect to the 55-day cropping cycle. CHI values are also included, since these indicate the amount of inedible biomass that must be channeled through the recycling subsystem, which typically involves energy-intensive procedures.

Seed composition analysis. To determine composition and estimate seed energy content, proximate analysis was performed on seed samples from the various treatment combinations. This procedure was as follows. Six to ten grams of seeds was ground for 30 sec using a mill (Micro Mill; Bell-Art Products, Pequannock, N.J.). Ground samples were analyzed for moisture, fat, protein, and ash content according to standard procedures of the Association of Official Analytical Chemists (AOAC) (1990). Moisture content of 2- to 3-g samples was determined by weight difference after drying the samples for $18 \mathrm{~h}$ in a vacuum oven at $70 \mathrm{C}$ and 3.3 $\mathrm{kPa} \mathrm{Hg}$ pressure. Seed oil content was determined by extracting 2to 3-g samples with petroleum ether for $8 \mathrm{~h}$ in a Soxhlet extraction unit. After evaporating the petroleum ether from the extract, residual fat was weighed. Protein and ash contents were then determined from the dry, defatted samples. Seed protein content was obtained using a micro-Kjeldahl method with a conversion factor of 6.25; this procedure has been detailed previously (AOAC, 1990). Ash content was determined by weight after incinerating samples in a muffle furnace at $550 \mathrm{C}$ for $18 \mathrm{~h}$. Moisture, oil, and ash contents were determined from triplicate samples, whereas seed protein content was determined from duplicate samples. Seed carbohydrate content was then calculated by difference [e.g., percent carbohydrate $=100 \%-($ percent moisture + percent protein + percent ash + percent fat)].

Model fitting and data analysis. The three-factor, three-level, completely randomized design used for this study (Box and Behnken, 1960) is specific for response surface designs involving second-order polynomials. The three factors investigated in this study included $\mathrm{N}$ level, time of $\mathrm{N}$ increase, and planting density (Table 1). The ambient- and elevated- $\mathrm{CO}_{2}$ experiments included 15 trials, 3 of which were replications of the experimental center point. This type of design reduced the two main sources of errorvariance and bias error (Box and Draper, 1959).

Data were analyzed using SAS's RSREG procedure (SAS Institute, Cary, N.C.). This software option provided second-order polynomial equations to model the crop response variables of interest. Analysis of variance provided information on the significance of each term in a given model and the extent of variable interactions. Model terms nonsignificant above $P=0.05$ were held at zero while grid points for that response model were generated.

Variable interactions were typically insignificant to our re- 
Table 3. Mathematical models used to represent crop response variables of dwarf, rapid-cycling brassica grown hydroponically under controlled-environment conditions.

\begin{tabular}{lcc}
\hline \hline Yield response & Model $^{\mathrm{z}}$ & $R^{2}$ \\
\hline & Ambient $\mathrm{CO}_{2}$ & 0.90 \\
Seed yield rate & $\mathrm{Y}=2.31-0.58 \mathrm{~N}+0.74 \mathrm{t}+1.01 \mathrm{t}^{2}$ & 0.78 \\
Shoot biomass & $\mathrm{Y}=24.38-7.3 \mathrm{t}$ & 0.92 \\
Seed oil content & $\mathrm{Y}=31.1-1.38 \mathrm{~N}+1.79 \mathrm{t}$ & 0.98 \\
$\mathrm{CHI}^{\mathrm{y}}$ & $\mathrm{Y}=12.42-3.79 \mathrm{~N}+7.89 \mathrm{t}+4.31 \mathrm{t}^{2}$ & 0.90 \\
& Elevated CO & 0.96 \\
Seed yield rate & $\mathrm{Y}=1.94+0.51 \mathrm{p}+0.5 \mathrm{t}^{2}$ & 0.97 \\
Shoot biomass & $\mathrm{Y}=41.37+6.63 \mathrm{~N}-8.19 \mathrm{t}$ & 0.97 \\
Seed oil content & $\mathrm{Y}=23.1-2.54 \mathrm{~N}+2.35 \mathrm{t}+3.05 \mathrm{t}^{2}$ & \\
CHI & $\mathrm{Y}=6.19-1.9 \mathrm{~N}+2.01 \mathrm{t}+1.37 \mathrm{p}+1.8 \mathrm{t}^{2}$ & \\
& &
\end{tabular}

${ }^{\mathrm{z}}$ Symbols $\mathrm{N}, \mathrm{t}$, and $\mathrm{p}$ in models represent $\mathrm{N}$ level, time of $\mathrm{N}$ increase, and planting density, respectively.

${ }^{\mathrm{y}} \mathrm{CHI}=$ caloric harvest index based on energy content of shoot biomass only.

sponse models. Therefore, no cross-product terms were included in any of the models (Table 3). This lack of interaction does not necessarily require data representation in one dimension. Graphically, we have presented our models as response surfaces in cases in which at least two experimental variables were significant. These three-dimensional response surfaces indicate the response range and the rate of change of the response due to the treatment variables.

Models were fitted to canopy seed yield rate, shoot biomass, and seed oil content directly from the harvest data. Shoot CHI was a calculated parameter that was determined before models were generated (Eq [1]). CHI was calculated as the ratio of calories in the seed to total calories in the shoot including the seeds (Sinha et al., 1982). For CELSS research, the energetic basis for CHI is appropriate since all biomass components must eventually flow through the food-processing and biomass-recycling stream, and the efficiency of this process depends largely on the chemical energy contained in the raw biomass. Also, since oil is 2.25 times more calorie dense than protein or carbohydrate (Merrill and Watt, 1955), CHI gives a relative measure of the energy partitioned into oil production.

$$
\mathrm{CHI}=\text { seed energy/shoot energy }
$$

where seed energy $=$ seed dry weight $\left[\left(\right.\right.$ percent fat $\left.\times 9 \mathrm{kcal} \cdot \mathrm{g}^{-1}\right)+4$ $\mathrm{kcal} \cdot \mathrm{g}^{-1}$ (percent protein + percent carbohydrate)] and shoot energy $=$ seed energy $+4 \mathrm{kcal} \cdot \mathrm{g}^{-1}$ (leaf dry weight + stem dry weight + silique shell dry weight).

Our preliminary experiments indicated that insignificant amounts of oil exist in the vegetative and silique shell material of this brassica species (data not shown). Therefore, the energy content of stems, leaves, and silique shells was estimated on a dryweight basis as $4 \mathrm{kcal} \cdot \mathrm{g}^{-1}$ times the quantity of vegetative biomass.

\section{Results}

Various mathematical models were developed to represent the crop responses in a statistically valid manner (Table 3). Model correlation coefficients $\left(R^{2}\right)$ ranged from 0.78 to 0.98 . The lack of fit statistic, an important consideration in developing response surface models, was insignificant at $P=0.1$ for all models derived in this experiment. No significant interactions were detected among the experimental variables. Therefore, no cross-product terms were included in any of the response models.

Canopy seed yield rate. Under ambient $\mathrm{CO}_{2}$ conditions, seed yield rate of brassica canopies was most sensitive to the time at which $\mathrm{N}$ was increased from $2 \mathrm{~mm}$ to a higher $\mathrm{N}$ level. The yield response was moderately sensitive $(P \leq 0.05)$ to $\mathrm{N}$ level, whereas planting density did not significantly affect canopy seed yield rate (Table 4). Seed yield response was quadratically related to the time of $\mathrm{N}$ increase; first- and second-order terms were significant to the response model (Fig. 1A). Canopy seed yield rate responded linearly to $\mathrm{N}$ level (e.g., first-order effect only), with yield rate decreasing as $\mathrm{N}$ level increased. The highest seed yield rate (4.4 $\mathrm{g} \cdot \mathrm{m}^{-2} \cdot$ day $^{-1}$ ) was obtained using ambient $\mathrm{CO}_{2}$ and $15 \mathrm{~mm} \mathrm{~N}$ initiated on day 28. According to the response model, a minimum seed yield rate of $1.6 \mathrm{~g} \cdot \mathrm{m}^{-2} \cdot \mathrm{day}^{-1}$ would occur if $\mathrm{N}$ were elevated to $30 \mathrm{~mm}$ on day 18 (Fig. 1A).

Under $\mathrm{CO}_{2}$ enrichment, planting density and time of $\mathrm{N}$ increase were the only significant factors affecting canopy seed yield rate

Table 4. Significance of experimental treatment variables to crop yield response models under nonsupplemented (ambient) and elevated $\mathrm{CO}_{2}\left(998 \mu \mathrm{mol} \cdot \mathrm{mol}^{-1}\right)$ conditions.

\begin{tabular}{|c|c|c|c|c|c|}
\hline \multirow[b]{2}{*}{ Variable } & \multicolumn{5}{|c|}{ Crop yield response } \\
\hline & $\mathrm{df}$ & Seed yield & Shoot biomass & Seed oil & $\mathrm{CHI}^{2}$ \\
\hline \multicolumn{6}{|c|}{ Ambient $\mathrm{CO}_{2}$} \\
\hline N level & 4 & $*$ & NS & $*$ & $*$ \\
\hline Time of $\mathrm{N}$ increase & 4 & $*$ & $*$ & $*$ & $* *$ \\
\hline Planting density & 4 & NS & NS & NS & NS \\
\hline \multicolumn{6}{|c|}{ Elevated $\mathrm{CO}_{2}$} \\
\hline $\mathrm{N}$ level & 4 & NS & $* *$ & $* *$ & $* *$ \\
\hline Time of $\mathrm{N}$ increase & 4 & $*$ & $* *$ & $* *$ & $* *$ \\
\hline Planting density & 4 & $*$ & NS & NS & $*$ \\
\hline
\end{tabular}

${ }^{\mathrm{z}} \mathrm{CHI}=$ caloric harvest index based on energy content of shoot biomass only.

Ns, ${ }^{*}{ }^{* *}$ Nonsignificant or significant at $P \leq 0.05$ or 0.01 , respectively. 


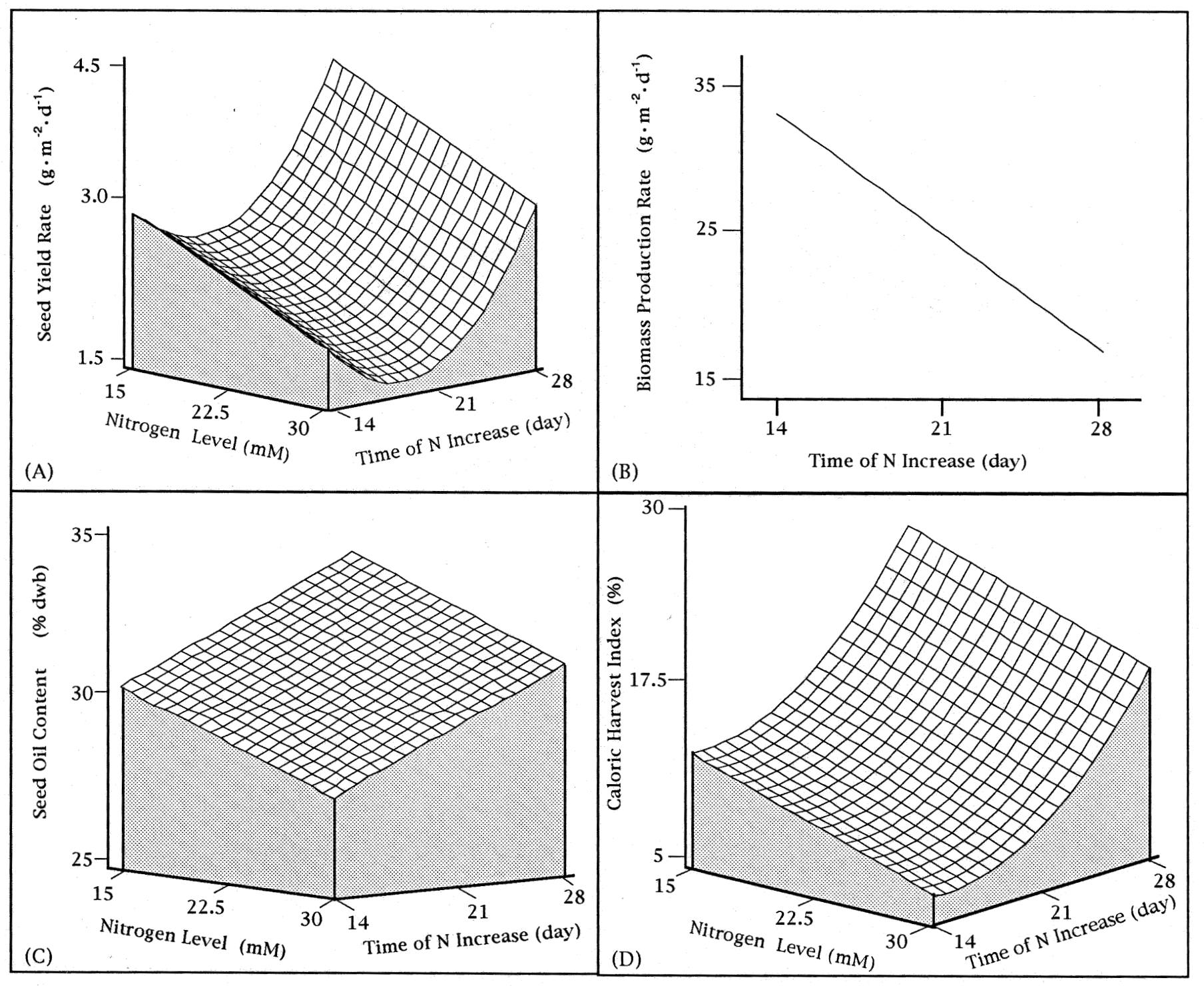

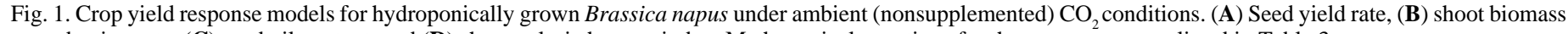
production rate, $(\mathbf{C})$ seed oil content, and (D) shoot caloric harvest index. Mathematical equations for these responses are listed in Table 3.

(Table 4). Yield rate increased linearly as planting density increased (Fig. 2A). Time of N increase influenced canopy seed yield rate quadratically, with only the second-order term significant to the model. Under elevated $\mathrm{CO}_{2}$ conditions, canopy seed yield rate was not affected by differences in $\mathrm{N}$ level.

Supplemental $\mathrm{CO}_{2}$ decreased canopy seed yield rate relative to nonsupplemented (ambient) $\mathrm{CO}_{2}$ for all treatment combinations tested. In general, yield rates were $15 \%$ to $34 \%$ lower than like treatments under ambient $\mathrm{CO}_{2}$ conditions. The maximum canopy seed yield rate obtained under elevated $\mathrm{CO}_{2}$ was $2.9 \mathrm{~g} \cdot \mathrm{m}^{-2} \cdot$ day $^{-1}$ and occurred at the highest planting density tested $\left(2093\right.$ plants $\left./ \mathrm{m}^{2}\right)$ and at the earliest time of $\mathrm{N}$ increase (Fig. 2A). A minimum seed yield rate of $1.4 \mathrm{~g} \cdot \mathrm{m}^{-2} \cdot$ day $^{-1}$ occurred at the lowest planting density (1163 plants $/ \mathrm{m}^{2}$ ) and when $\mathrm{N}$ was increased on day 21 .

Shoot biomass production rate. Under ambient $\mathrm{CO}_{2}$ conditions, total shoot biomass production rate was responsive only to time of $\mathrm{N}$ increase (Table 4). Neither $\mathrm{N}$ level nor planting density significantly affected shoot biomass production. The rate of biomass production and time of $\mathrm{N}$ treatment were inversely related in a linear fashion (Fig. 1B). A maximum shoot biomass production rate of $31.7 \mathrm{~g} \cdot \mathrm{m}^{-2} \cdot \mathrm{day}^{-1}$ was obtained under ambient $\mathrm{CO}_{2}$ conditions and when $\mathrm{N}$ was increased at the earliest treatment time (day 14). A minimum biomass production rate of $17.8 \mathrm{~g} \cdot \mathrm{m}^{-2} \cdot \mathrm{day}^{-1}$ occurred when $\mathrm{N}$ was elevated at the latest treatment time tested (day 28).

Under enriched $\mathrm{CO}_{2}$ conditions, $\mathrm{N}$ level and time of $\mathrm{N}$ increase were highly $(P \leq 0.01)$ significant factors affecting shoot biomass production rate (Table 4). Shoot biomass accumulation rate increased linearly as $\mathrm{N}$ level increased, but decreased linearly as the time of $\mathrm{N}$ increase was delayed (Fig. 2B). Planting density did not significantly affect the biomass production rate. With $\mathrm{CO}_{2}$ enrichment, a maximum biomass production rate of $55.5 \mathrm{~g} \cdot \mathrm{m}^{-2} \cdot$ day $^{-1}$ was obtained when $\mathrm{N}$ was increased at the earliest time (day 14) and to the highest $\mathrm{N}$ treatment level $(30 \mathrm{~mm})$. A minimum biomass production rate $\left(27.4 \mathrm{~g} \cdot \mathrm{m}^{-2} \cdot \mathrm{day}^{-1}\right)$ occurred under the opposite treatment combination (i.e., lowest $\mathrm{N}$ level applied at the latest treatment time). Supplemental $\mathrm{CO}_{2}$ increased shoot biomass production at all treatment combinations tested. In general, shoot biomass rate was $54 \%$ to $75 \%$ greater than like treatments in the ambient- $\mathrm{CO}_{2}$ experiment. 


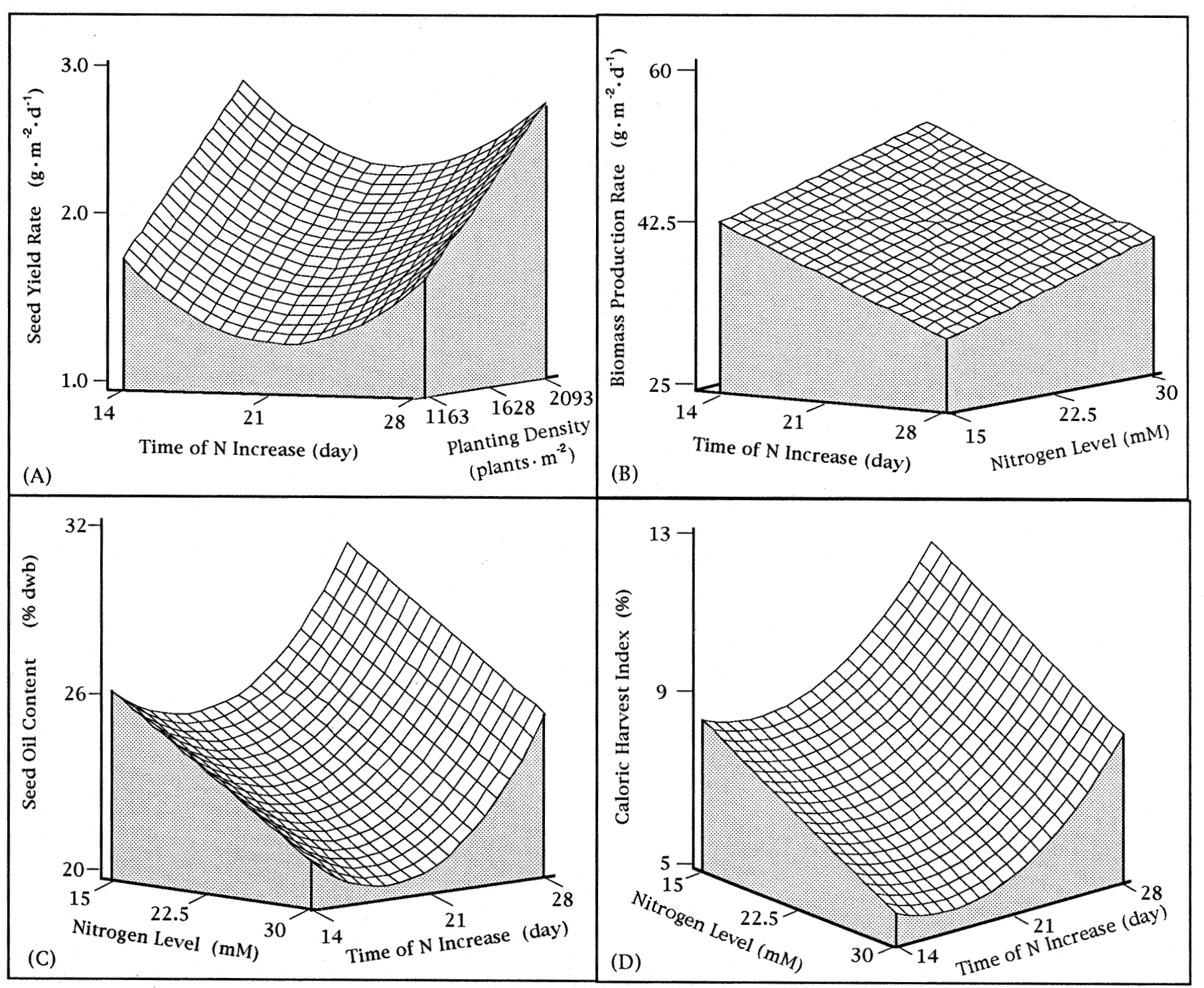

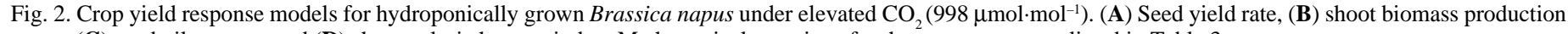
rate, $(\mathbf{C})$ seed oil content, and (D) shoot caloric harvest index. Mathematical equations for these responses are listed in Table 3.

Seed oil content. Under ambient $\mathrm{CO}_{2}$ conditions, the time at which $\mathrm{N}$ was increased and final $\mathrm{N}$ level had the most significant impact on seed oil content (Table 4), with oil content responding linearly to the effects from these treatment variables. The response was inversely proportional to $\mathrm{N}$ level but directly proportional to time of N increase (Fig. 1C). Planting density did not significantly affect the oil content of the brassica seeds. Maximum seed oil content of $34.1 \%$ (dry weight basis) occurred under ambient $\mathrm{CO}_{2}$ conditions when $\mathrm{N}$ was increased to $15 \mathrm{~mm}$ on day 28. A minimum oil content of $28.1 \%$ occurred with $30 \mathrm{~mm} \mathrm{~N}$ applied on day 14 .

Under $\mathrm{CO}_{2}$ enrichment, seed oil content was highly $(P \leq 0.01)$ sensitive to $\mathrm{N}$ level and time of $\mathrm{N}$ increase (Table 4). Planting density did not affect seed oil content. Seed oil content declined linearly as N level increased, while time of N increase affected seed oil content in a quadratic fashion with the first- and second-order terms significant to the model (Fig. 2C). Compared to the ambient$\mathrm{CO}_{2}$ experiment, supplemental $\mathrm{CO}_{2}$ had little effect on maximum seed oil content. A maximum oil content of $30.2 \%$ was obtained when $\mathrm{N}$ level was increased to $15 \mathrm{~mm}$ at the latest treatment time (day 28). The minimum seed oil content (20.4\%) occurred when 30
mM N was applied at an early treatment time (day 18).

Shoot $\mathrm{CHI}$. Under ambient $\mathrm{CO}_{2}$ conditions, $\mathrm{CHI}$ was sensitive to the time of $\mathrm{N}$ increase (Table 4). Linear and quadratic terms were significant to the CHI response model (Fig. 1D). N level was moderately significant, with $\mathrm{CHI}$ decreasing linearly as $\mathrm{N}$ level increased. Planting density did not significantly affect the $\mathrm{CHI}$ response. The maximum $\mathrm{CHI}$ obtained under ambient $\mathrm{CO}_{2}$ conditions was $26.8 \%$, and it occurred when $\mathrm{N}$ was increased to $15 \mathrm{~mm}$ on day 28 . The minimum CHI (5.4\%) occurred under an opposite treatment scenario (e.g., $30 \mathrm{~mm} \mathrm{~N}$ applied on day 14).

In general, $\mathrm{CO}_{2}$ enrichment favored vegetative growth and inhibited the onset of reproductive development and senescence. As a result, $\mathrm{CO}_{2}$ enrichment greatly reduced shoot $\mathrm{CHI}$ at all treatment combinations tested. Under elevated $\mathrm{CO}_{2}$ conditions, all three experimental variables significantly affected the $\mathrm{CHI}$ response (Table 4). However, $\mathrm{N}$ level and the time of $\mathrm{N}$ increase were the most significant variables (Fig. 2D). In the elevated- $\mathrm{CO}_{2}$ experiment, the maximum $\mathrm{CHI}$ was only $12.6 \%$ and occurred with $15 \mathrm{~mm} \mathrm{~N}$ applied on day 28 and with a cropping density of 2093 plants $/ \mathrm{m}^{2}$. The response model predicted a minimum CHI of $2.6 \%$ 
if $\mathrm{N}$ was elevated to $30 \mathrm{~mm}$ on day 17 and for a planting density of 1163 plants $/ \mathrm{m}^{2}$.

\section{Discussion}

The main purpose of starting brassica canopies on $2 \mathrm{~mm} \mathrm{~N}$ (15 mM is considered single-strength $\mathrm{N}$ for Hoagland's no. 1 nutrient solution) was to discourage extensive vegetative growth and to establish the dense plant populations evaluated in this study. The $2 \mathrm{~mm} \mathrm{~N}$ level favored formation of unbranched stems and small, pale-green leaves, consistent with previous reports of $B$. napus grown in solution culture with limiting N (Yau and Thurling, 1987). In our study, leaves regained normal color and size in treatment groups receiving higher $\mathrm{N}$ at an early application time. However, initial leaves underwent early senescence and abscission in treatment groups receiving limiting $\mathrm{N}$ for longer periods of time (days 21 to 28 ).

Another purpose of applying low $\mathrm{N}$ was to evaluate its effect on seed oil content. The growth-limiting $2 \mathrm{~mm} \mathrm{~N}$ enhanced seed oil content, with maximum oil content (34\%, dry weight basis) occurring when plants received $2 \mathrm{~mm} \mathrm{~N}$ for the longest treatment time (28 days). Since this treatment combination was consistent with maximum seed yield rate, it seems possible to maximize seed oil content and seed yield rate simultaneously by restricting $\mathrm{N}$ nutrition.

With respect to planting density, previous reports regarding seed yield of oilseed rape have been mixed. Other researchers have shown seed yield in open-field agriculture to decrease as plant population decreased (Clark et al., 1978; Kondra, 1977; Rao and Mendham, 1991). Still other studies have revealed little or no change in seed yield with changes in planting density (Kondra, 1975; Singh and Yusurf, 1978). At low cropping densities, rapeseed compensates by increased branching and by producing more siliques per plant (Clarke and Simpson, 1978a, 1978b; Clarke et al., 1978). Compensation may explain the relative insignificance of planting density on seed yield as observed in our ambient $\mathrm{CO}_{2}$ experiment. However, in the elevated $\mathrm{CO}_{2}$ experiment, planting density was the most significant experimental variable. Since $\mathrm{CO}_{2}$ enrichment increased total shoot biomass per unit area, crowding and interplant competition for space, water, and nutrients likely enhanced the relative significance of planting density to the seed yield response.

With regard to seed oil content and planting density, results of the present study were consistent with published reports from previous research, most of which were field studies. Kondra (1975) found effects of row spacing and seeding rate to be insignificant on seed oil content of 'Zephyr' B. napus. In addition, seed oil and protein contents were unaffected by seeding rate in similar experiments (Morrison et al., 1990; Scarisbrick et al., 1982)

Increasing $\mathrm{N}$ fertilization rates have increased seed production of oilseed rape in field studies (Henry and MacDonald, 1978; Scott et al., 1973; Sheppard and Bates, 1980; Wright et al., 1987). In the present controlled-environment, hydroponic study, $\mathrm{N}$ concentration typically was of secondary importance, whereas the time of $\mathrm{N}$ increase generally was more significant to the seed yield response. The maximum seed yield rate in the ambient- and $\mathrm{CO}_{2}$-enriched experiments occurred at relatively low $\mathrm{N}$ treatment levels. This result suggests that $\mathrm{N}$ concentrations $>15 \mathrm{~mm}$ may saturate the seed yield response for this species in hydroponic crop production.

Increasing $\mathrm{N}$ nutrition has stimulated shoot biomass growth of oilseed rape in field (Mendham et al., 1981; Wright et al., 1987) and controlled-environment studies (Malhi et al., 1988; Rood and
Major, 1984). We found similar responses, especially under elevated $\mathrm{CO}_{2}$ conditions. The combination of high $\mathrm{CO}_{2}$ and high $\mathrm{N}$ greatly increased shoot biomass production rates, which were consistently higher than those of identical $\mathrm{N}$ treatments under ambient $\mathrm{CO}_{2}$ conditions. Since the shoot biomass response did not plateau at the highest $\mathrm{N}$ treatment tested $(30 \mathrm{~mm})$, further vegetative growth stimulation may occur at even higher $\mathrm{N}$ concentrations.

The effects of various $\mathrm{N}$ fertilization regimes on seed oil content also have been tested in field trials (Henry and MacDonald, 1978; Scott et al., 1973; Sheppard and Bates, 1980). In all of these studies, seed oil content decreased with increasing N level. Seed oil also decreased with increasing N level in a study by Smith et al. (1988), who reported an inverse relationship between seed oil content and $\mathrm{N}$ (protein) accumulation. Similar results were found in the present controlled-environment, hydroponic crop growth study.

Shoot CHI was greatest when $\mathrm{N}$ remained limiting $(2 \mathrm{~mm})$ for the longest treatment time ( 28 days). Low $\mathrm{N}$ favored oil accumulation by the seeds. The $2 \mathrm{~mm} N$ level also decreased stem and leaf biomass, which in turn reduced the energy contribution of vegetative biomass. Although $\mathrm{CO}_{2}$ enrichment did not affect seed oil content, it greatly reduced shoot $\mathrm{CHI}$. Supplemental $\mathrm{CO}_{2}$ increased nonedible vegetative biomass and delayed seed production, which lowered the proportion of seed energy to total shoot energy. Therefore, continuous enrichment of atmospheric $\mathrm{CO}_{2}$ does not seem advantageous to increasing seed yield rate or shoot $\mathrm{CHI}$ of this brassica species.

Since the maximum $\mathrm{CHI}$ and shoot biomass production rates occurred under opposite treatment scenarios, it does not seem possible to optimize these two harvest variables simultaneously with respect to $\mathrm{N}$ nutrition. This implies a yield trade-off and may be used advantageously in an operating CELSS by increasing system flexibility. For example, high $\mathrm{N}$ could be used in some hydroponic systems to stimulate rapid vegetative biomass production. In turn, this would facilitate $\mathrm{C}$ uptake, scrubbing $\mathrm{CO}_{2}$ more quickly and replacing it with $\mathrm{O}_{2}$ for human respiration. Other hydroponic systems might use more moderate $\mathrm{N}$ to optimize seed and oil production as these resources are needed by the crew.

Compared to other potential oilseed crops for a CELSS (peanut and soybean), dwarf, rapid-cycling brassica seems competitive. Seed oil of B. napus is higher in monounsaturated fatty acids than either peanut or soybean oil and it is lower in polyunsaturated fatty acids than soybean oil (Stanton, 1993). In addition to oil production, brassica leaves are readily edible as a Ca-rich, fresh salad vegetable (Tufts University, 1990). Therefore, a mixed harvest and cultural strategy may increase harvest index and allow this species to be used to its fullest potential. For dwarf brassica to remain a viable oilseed candidate, such cultural procedures must be refined further.

In summary, different $\mathrm{N}$ nutrition regimes had a large impact on canopy seed yield rate, total shoot biomass, seed oil content, and shoot CHI of dwarf, rapid-cycling brassica. Low to moderate $\mathrm{N}$ levels in hydroponic nutrient solution (up to $15 \mathrm{~mm}$ ) seem to favor seed yield rate and seed oil content, whereas higher N (15 to $30 \mathrm{~mm}$ ) decreased these harvest variables of interest. Elevated $\mathrm{CO}_{2}$ increased total vegetative biomass but decreased seed yield rate by delaying reproductive development and senescence. This study also showed that seed composition of this brassica species can be readily altered by varying nutritional regimes in hydroponic nutrient solutions. This quality will be particularly important in a CELSS, where integrated environmental management will be used to influence biomass production rates and the food value associated with crop harvests. 


\section{Literature Cited}

Association of Official Analytical Chemists. 1990. Official methods of analysis. 15th ed. Assn. Offic. Anal. Chemists, Arlington, Va.

Box, G.E. and D.W. Behnken. 1960. Some new three level designs for the study of quantitative variables. Technometrics 2(4):455-475.

Box, G.E. and N.R. Draper. 1959. A basis for the selection of a response surface design. J. Amer. Stat. Assn. 54:622-654.

Clarke, J.M., F.R. Clarke, and G.M. Simpson. 1978. Effect of method and rate of seeding on yield of Brassica napus. Can. J. Plant Sci. 58:549-550.

Clarke, J.M. and G M. Simpson. 1978a. Influence of irrigation and seeding rates on yield and yield components of Brassica napus cv. Tower. Can. J. Plant Sci. 58:731-737.

Clarke, J.M. and G.M. Simpson. 1978b. Growth analysis of Brassica napus cv. Tower. Can. J. Plant Sci. 58:587-595.

Henry, J.L. and K.B. MacDonald. 1978. The effect of soil and fertilizer nitrogen and moisture stress on yield, oil and protein content of rape. Can. J. Soil Sci. 58:303-310.

Hoagland, D.R. and D.I. Arnon. 1950. The water culture method for growing plants without soil. Univ. of California, Berkeley, Expt. Sta. Circ. 347.

Hoff, J.E., J.M. Howe, and C.A. Mitchell. 1983. Nutritional and cultural aspects of plant species selection for a regenerative life support system. NASA Contractor Rpt. no. 166324.

Kondra, Z.P. 1975. Effect of row spacing and seeding rate on rapeseed. Can. J. Plant Sci. 55:339-341.

Kondra, Z.P. 1977. Effect of planted seed size and seeding rate on rapeseed. Can. J. Plant Sci. 57:277-280.

Malhi, S.S., M. Nyborg, H.G. Jahn, and D.C. Penney. 1988. Yield and nitrogen uptake of rapeseed (Brassica campestris L.) with ammonium and nitrate. Plant and Soil 105:231-239.

Mendham, N.J., P.A. Shipway, and R.K. Scott. 1981. The effects of seed size, autumn nitrogen and plant population density on the response to delayed sowing in winter oil-seed rape (Brassica napus). J. Agr. Sci. Cambridge 96:417-428.

Merrill, A. and B. Watt. 1955. Energy value of foods, basis and derivation. Human Nutr. Res. Branch, Agr. Res. Serv., U.S. Dept. of Agr., U.S. Govt. Printing Offices, Washington, D.C. Agr. Hdbk. no. 74, p. 105.

Milthorpe, F.L. and J. Moorby. 1979. An introduction to crop physiology. Cambridge Univ. Press.
Morrison, M.J., P.B. McVetty, and R. Scarth. 1990. Effect of row spacing and seeding rates on summer rape in southern Manitoba. Can. J. Plant Sci. 70:127-137.

Rao, M.S. and N.J. Mendham. 1991. Comparison of chinoli (Brassica campestris subsp. oleifera $\mathrm{X}$ subsp. chinensis) and B. napus oilseed rape using different growth regulators, plant population densities and irrigation treatments. J. Agr. Sci. Cambridge 117:117-187.

Rood, S.B. and D.J. Major. 1984. Influence of plant density, nitrogen, water supply and pod or leaf removal on growth of oilseed rape. Field Crops Res. 8:323-331.

Scarisbrick, D.H., R.W. Daniels, and A.B. Noor Rawi. 1982. The effect of varying seed rate on the yield and yield components of oil-seed rape (Brassica napus). J. Agr. Sci. Cambridge 99:561-568.

Scott, R.K., E.A. O'Gunremi, J.D. Ivins, and N.J. Mendham. 1973. The effect of fertilizers and harvest date on growth and yield of oilseed rape sown in autumn and spring. J. Agr. Sci. 81:287.

Sheppard, S.C. and T.E. Bates. 1980. Yield and chemical composition of rape in response to nitrogen, phosphorous and potassium. Can. J. Soil Sci. 60:153.

Singh, S.D. and M. Yusurf. 1978. Effect of water, nitrogen and row spacing on yield and oil content of brown sarson. Can. J. Plant Sci. 59:437-444.

Sinha, S., S. Bhargava, and A. Goel. 1982. Energy as the basis of harvest index. J. Agr. Sci. Cambridge 99:237-238.

Smith, C.J., G.C. Wright, and M.R. Woodroofe. 1988. The effect of irrigation and nitrogen fertilizer on rapeseed (Brassica napus) production in south-eastern Australia. II. Nitrogen accumulation and yield. Irr. Sci. 9:15-25.

Stanton, J. 1993. Canola in the United States. Cereal Foods World 38(7):483-485.

Tufts University. 1990. Hail kale. Tufts Univ. Diet and Nutr. Lett. vol. 8, no. 5.

Wade, W.C. 1989. Nutritional models for a controlled ecological life support system (CELSS): Linear mathematical modeling. NASA Contractor Rpt. no. 4229.

Wright, G.C., C.J. Smith, and M.R. Woodroofe. 1987. The effect of irrigation and nitrogen fertilizer on rapeseed (Brassica napus) production in south-eastern Australia. I. Growth and seed yield. Irr. Sci. 9:1-15.

Yau, S.K. and N. Thurling. 1987. Variation in nitrogen response among spring rape (Brassica napus) cultivars and its relationship to nitrogen uptake and utilization. Field Crops Res. 16:139-155. 